\title{
Environmental Art Professional Teaching Reform of Landscape Design Chunyan Shi
}

Department of Environmental Art Design, Hebei Institute of Fine Art ,ShiJiazhuang Hebei, 050700, China

Keywords: landscape design; Environmental art; The teaching reform

\begin{abstract}
This paper analyzes the teaching situation present about the landscape design course at home and abroad, discussed on the problems specialty existing in the landscape design of environmental art courses, put forward a series of teaching reform measures in allusion to the problem of the existence. Thinking about teaching system construction and teaching methods for the landscape design of environmental art. Provides a certain theoretical basis for the landscape design course teaching reform Landscape design course. In order to better meet the social demand for landscape design talent, and better enrich landscape professional was perfected in China, getting a further research in order to establish a new diversified teaching pattern of the landscape design.
\end{abstract}

\section{Introduction}

In recent years, with rapid urbanisation exhibition, there has been called "the second nature" city landscape demand is higher and higher, the demand of society to the professionals engaged in landscape design, at the same time also brought the vigorous development of landscape science, agricultural colleges, school of architecture, the arts colleges and universities have set up courses on landscape design. Through constant development, landscape design courses has been occupies an important position in the environmental art design major, is a for the purpose of cultivating professional talents of comprehensive applied design professional design process. Landscape design is the perfect fusion of artificial factors and natural factors, human art and the rational combination of science and technology [1]. Landscape design course is different from the urban planning design and architecture design professional teaching category, from the Angle of the environmental art design, it includes the urban planning and design, architecture design, plant configuration and landscape design, water design, ecological design, and many other design content, is a new development in the field of environmental art design. After recent years of development, landscape planning course has been occupies an important position in the environmental art design major, teaching and achieved certain results, but because of the development of the time soon, the current environmental art professional courses in landscape design also has certain problem, the quality of teaching also has the very big development space, reasonable teaching system also needs to be built. With the development of the society, people's income is growing, constantly improve the education level, ecological environment is deteriorated, and people's living, leisure environment quality put forward higher requirements, the organization form of urban space and design requirements into landscape design of the important research subject. The professional landscape design, in China is a great opportunity, and a great challenge. How to develop the education of landscape design in our country, the landscape design course teaching system, training of the new era of landscape designer is an important task in front of us.

Modern design practice in the field of extensity requires the designer with whole, integrated and comprehensive knowledge background, so the landscape design should combine scientific and artistic analysis, the planning and design, management, protection and content included. Accordingly, the landscape design teaching should pay attention to social, ecological and the trinity of art, should not be ignored. Now under the background of education in our country, we should be the subject of landscape design education system to constantly adjust, emphasis on environmental science and the humanities society, absorbing the latest research achievements of other disciplines, reform teaching methods, with an open attitude, eventually to aiming at the sustainable development of the living environment of the holistic landscape design education. 


\section{The Botanical Garden Landscape Design and Its Teaching Status Quo}

The Current Situation of Development of Landscape Design. At present, with the advancement of urbanization, the urban environment deteriorating, man-made destruction has made the environment's ability to repair itself is reduced greatly. As to the ecological idea, to enhance people environmental protection consciousness, lift their quality of life. In the development of the city, became an indispensable part of landscape, landscape design and rapid development, the construction of landscape, the upgrade of show gardens and energy has become one of the important concept of landscape design. Science and technology, biological technology such as domesticated, cross culture continues to advance, to landscape design is more vast resources available, mechanics and architecture construction progress of the work also brings the landscape design of artificial elements more technical support. Artistic creation, created a batch with local characteristics, culture landscape design work, but there are still ignore the garden landscape view of the construction of the regional, standardization and mass production of garden products many problems such as lack of personality, especially I have China, the landscape design industry is still very young, will also face more opportunities and challenges. Overall, the landscape design is toward sustainable development, follow the principle of ecology, more rapid development of the science and technology, more human direction. Ring art students from arts college entrance examination enrollment, major landscape in relative to the student, has the stronger ability of art creativity and graphic expression, but its deviation in science and engineering knowledge, understanding of space and design ability is relatively weak. For a long time, ring arts professional works of many students have heavy performance characteristics of light content, emphasized the beautiful form in the process of design is novel, but seldom consider the most basic function, so can only be of good draftsman and can't be a good designer. To this, many students also feel confused, oneself use four years through college courses, found work may and vocational technical secondary school graduates, even on the use of drawing software proficiency is worse than the latter. Relative to the cultivation of higher vocational colleges and universities career guidance, technical secondary school at the university of education on the quality and ability training as the guide, for ring arts major, which is to cultivate students ability of design quality and design thinking.

In the unit teaching, landscape design class is usually in a professional basic course and interior design class before. Students through a series of interior space and the corresponding design practice, has formed relatively strong interior space, microscopic and meticulous way of thinking, and the use of perspective for the design of the visual expression way. Into the landscape design course, want to shift to more large-scale outdoor space design, especially in relatively more abstract plan for designing idea and expression, difficult to adapt to, on the scale of space form and spatial ability is weak, need to try to guide teachers consciously, make its sense and measure concept gradually formed outdoor places.

Foreign Landscape Design Course Teaching. Landscape design originated in the United States, founded by the father of landscape olmsted. In 1900, olmsted opening landscape design courses at Harvard University, the development so far, American landscape architecture at Harvard University has one hundred years history, cultivate a large number of outstanding landscape design masters. [2] Cultivate the future landscape architect professional skills and the ability to tie the industry is the goal of landscape architecture at harvard is insist on. 40 courses are divided into three categories: design class, lectures and seminars, independent study class. Emphasizing both the basis of landscape history, plants, the basic theoretical knowledge, such as climate, soil, and pay attention to the design, building structure, plant physiological knowledge, at the same time also cultivate the students' drawing and computer graphics and other art creation technique and ability. Teacher is also very good landscape designer or arts to create master, every teacher have their own characteristics and is good at the direction of the design according to the teacher itself characteristics, open courses can also make the students learn more professional knowledge. Lectures and discussions, is the combination of theory and practice to make students have more solid basic skills, more special ability to innovate. Research on foreign current situation of landscape design course teaching is of great significance to our country of the teaching of the major. 


\section{Domestic Environmental Art Professional Landscape Design Problems Existing in the Course}

The landscape design of curriculum in China starts late, but development speed, in many colleges and universities are open landscape design professional, including agriculture and forestry colleges and universities, mainly lay particular stress on the student the direction of the plant to plant and use, also rolled with the landscape architectural design major, more focus on landscape architecture and technology direction, art college in the landscape design basic belongs to environmental art specialty, focus on aesthetics and artistic direction, and all kinds of colleges and universities are often at the same time there is a landscape design, landscape planning and design, construction, etc.

On the whole, the professional setting is relatively chaos, than there is a big gap with foreign landscape design professional. Among them, the landscape design course in art college of environmental art specialty setup and arrange also has certain problem. In recent years, rapid progress in the development of landscape ecology, scientific research emerge in endlessly, applications continue to expand, to the current relatively fixed challenge course teaching pattern of landscape ecology, in both the course construction and teaching reform, there are many problems to be solved.

Landscape Design Courses Setting Reasonable Enough. At present, the art department of environmental art professional landscape design runs only landscape design, landscape architecture design two courses. [3] For some basic design course of landscape design courses seriously enough, such as: courses such as botany, ecology, causing students learning design without open field of vision and solid basic skills, increase the foundation course of landscape design, to cultivate students to adapt to the development of future landscape industry needs.

Lack of Practice Content. At present, the landscape design course lack of practice teaching for students, landscape design need to master the strong professional knowledge and ability, students mastery of basic knowledge is only limited to the classroom, can not be intuitive knowledge. Landscape design need to visit more live, know a lot of garden plant, learn to garden conception and layout in practice.

To the Landscape Design Class Professional Teachers Team Construction is not Enough. Garden specialty in the process of constant progress, the content of the discipline and knowledge are constantly updated, so the landscape design professional must be with the development of the society and the improvement of people's aesthetic standards. Garden professional teachers to keep learning and progress, rich knowledge and experience in teaching.

Course Examination Way of Simplifying Assumptions. Curriculum evaluation is to examine the effects of course one of the effective means, is an important part in the teaching, but in the current domestic landscape design course examination way, basic limitations in due course design assignments this is relatively single traditional way. Due to the landscape design course with strong practicality and knowledge content of cross particularity, the single way of examination can not comprehensive, integrated, in-depth investigation of students learning the course of real and effective results.

Teaching Subject Simplification in Social Practice. The content of the andscape design has a wide range, including residential area landscape design, square landscape design, urban park landscape design, the street landscape design, and other types. However, in the domestic landscape design of the teaching subject, often hard to make a choice, the various types of landscape design task and can only be one or two types of them to make specific training. This relatively single topic selection mode of teaching, to cultivate comprehensive and high quality practical type, landscape design talent, hard to do better meet the social demand for landscape design talent.

Single Teaching Method. The domestic landscape design of the course is usually adopt the teaching methods of theory + design practice, for the landscape design of the relatively strong practical work, this kind of teaching method is too single, for many students real actual content is difficult to grasp. Such as various types of landscape space scale and the scale of the landscape space in difficult to accurately; Suffering of landscape space in the sense of reality In order to achieve real; On the landscape design of artificial environment color in photograph reflect with light color changes Difficult to intuitive feelings. 


\section{The Landscape Design Course Teaching Reform Measures}

In extensive reference to domestic and foreign many colleges and universities teaching reform pattern, on the basis of combination of forestry college of fujian agriculture and forestry university landscape ecology construction course, on how to strengthen the course construction of landscape ecology, innovation of teaching content reform and teaching practice, aiming at build a vibrant, rich in content, the diversification of teaching means, commonness and personality unity and operability of the landscape ecology teaching mode, to promote quality education and the cultivation of innovative talents to provide the reference.

To Construct the Teaching System. According to the problem of the unreasonable curriculum, we in the landscape design course teaching system reform, should increase the related supporting course. Such as ecology, landscape architecture itself is for urban ecosystem service, students only have a concept of ecology, to make up to the standard of ecological landscape design. Such as Chinese and western landscape history again, make a design first should have a solid theoretical foundation and vast horizons, Chinese and western landscape history study is necessary. [4] Ecology, history of Chinese and western gardens, plant configuration and landscape of the related can greatly improve the quality of teaching on the course of landscape design, knowledge wider and all-inclusive, enable students to master the knowledge of landscape design.

To Strengthen the Construction of Teaching Staff. To build a professional, high level and high quality teaching staff, is vital for landscape design curriculum reform, teacher's quality decides the quality of teaching. First of all, the school can various imported high quality landscape design professionals, such as strengthen the communication with famous universities, professors to give lectures, employ well-known designers open lecture, send out the teachers training learning, encourage the school teachers to improve their education, teachers than deserve to make reasonable proportion garden professional teachers and art teachers. Second, the teachers themselves to learning Improve, not only limited to book knowledge, to participate in the design practice, this design can better guide the student subject. Perfecting the teaching archives, constantly adjust the teaching plan according to the characteristics of students, improve teaching methods, improve teaching quality.

To Strengthen the Practice and Theory Combining with the Actual. Design courses is inseparable from the practice, through practice courses, make students not only confined to the book knowledge, but combined with the actual, know society, improve the beginning ability. [5] Such as to carry out the project design, project design can be a practical engineering society, from the investigation to the scheme design, let the student to complete the whole design process of the project, can let them understand the actual operation of the design, but also greatly improve the ability to design. In classroom teaching, also can increase the case, the interpretation of the works by masters in landscape design, the social fashion design gimmick Can greatly widen students horizons. At the same time can also carry out practice teaching outside the classroom, with students to visit have color landscape design works, make the analysis and evaluation, absorb the experience and lessons from the instance, intuitive understanding of the plant, stone garden natural elements, such as a large amount of material for the later design. Only in the application of theoretical knowledge to actual design, can effectively improve students' ability in design.

The Teaching Aim of "the Trinity". Landscape design course is a practical design course, design process is a from function to form, and from form to function more stages of creative thinking activity, through vision, planning, implementation and production process. Landscape design, therefore, the teaching goal of the course include at least the following three kinds of ability, thinking ability, research ability and design ability to express the three complement each other, be short of one cannot.

Design Thinking Ability. Environmental art professional to develop the students' ability of thinking in design, landscape design as one of the important courses, more emphasis on the design thinking ability of students, to guide the student to carry on the viewing Angle and directional thinking, to find and try to solve the problem of various methods. Design, however, the cultivation of thinking ability is a long and gradual process, can't be through theoretical teaching and the 
students to master, can only be guided in the process of design practice, this requires teachers to communicate with students, to discuss ways to guide students to think deeply and active innovation.

Research and Analysis Ability. Landscape design is a beautify the problem not only, more is a combination of technology and art courses, therefore, the landscape design course teaching should also pay attention to the combination of art and science and technology knowledge, with emphasis on the design thinking and cultivate students creative rational research and analysis ability. In the teaching, the cultivation of the ability of students to design and analysis can be done through do more scheme evaluation. For design students, pointed out its problems existing in the design of, encourage students themselves to find solution to find information. In addition, social investigation in the design courses, is also a important way to cultivate students' ability to research and analysis. According to the selected topic, organizes the student to give you into urban social investigation, on the basis of further research, understand the landscape and architecture, landscape and city, the relationship between landscape and environment, to cultivate students found the problem, the ability to analyze and solve problems.

Design Skills. Design expression ability mainly includes the hand-painted performance ability, ability to computer aided performance, model making, performance skills and language ability. With good communication skills, design thinking to intuitively physical and chemical performance, so as to be understanding and interpretation. Good communication skills, in turn, can also help inspire, train the ability of design thinking. Ring arts students already has the characteristics of high artistic accomplishment, model ability, the design expression occupies a certain advantage, but should avoid engineering drawing is not rigorous, practicality is not strong. Language power of expression will be simulated to design report and organize groups to discuss ways to develop.

\section{Present Problems of the Landscape Design Course Experimental Teaching}

Landscape design course experiment teaching is one of the important link of the professional personnel training, improve experiment teaching quality is landscape professional teaching concerns of many colleges and universities. At present our landscape design experiment teaching exist the following problems:

(a)Single teaching mode give priority to with theory teaching, combined with some examples. Students understand and grasp the low efficiency of the teaching content;

(b)With the landscape design teaching is most individual students to experiment, causes students lack of team cooperation training and special training; At the same time, due to the lack of communication, the lack of design expression, so as to affect the final quality of the landscape design works;

(c)Some experimental teaching content with mechanically routines or use for a long time, and the present teaching situation has disconnect, can not play the role of linking up theory with practice;

(d)Organizing teaching inflexible, basically are all teachers to teach, and students in accordance with the requirements for the design plan descriptions of the design pattern. Teachers just in guiding students' class time in the process of design, not fully arouse the enthusiasm of students;

(e)Lack of actual combat training in experiment teaching. In experiment teaching of landscape design, basically all is a set of commitments to coordinate, specification of subject is usually in the teacher to give priority to, few real feasible design project was introduced into the experimental teaching.

\section{The Landscape Design Course Reform Measures of Experimental Teaching Method}

Landscape design for more than teaching the existing problems, combining the reality of the sichuan university institute of architecture and environment, new experimental teaching method was introduced to the landscape design in the teaching. On the one hand, due to the landscape design which combines artistry and practicality, emphasis on cultivating students' creative ability and practice ability; On the other hand, due to the sensitivity of the professional school of architecture 
and environmental design in colleges and universities also made many discussion topic. Therefore, transformation of sichuan university of architecture environment and existing atrium roof greening design competitions are introduced into the landscape design experiment teaching of the course .

The Introduction of the Design Competition Project. Design Competition Project Background. Sichuan university school of architecture and environment building located in the sichuan university campus, designed in 2003, completed in 2005, a total construction area of $11000 \mathrm{~m}^{2}$. Due to the limited funds to build, at that time and condition, the atrium of the building environment and ill-advised roof virescence design, use the following problems:

(a)The atrium environment as an important places of public communication of teachers and students of architecture, at present has not been fully used. Investigate its reason, it is due to the limitation of the current traffic flow, because the atrium environment too drab, basic can't use;

(b)The roof in many colleges and universities have also been communication as an open place, but because has not been good management, and the way of reach is limited, therefore has not been used;

(c)For landscape architecture professional teachers and students, building and surrounding ring buildings that can hardly to do teaching practice base in plant field.

Above existing problems and the school of architecture and the environment building of the building environment and greening design requirements of the atrium, just as the opportunity of teaching reform project. In addition, the professional education in addition to the professional curriculum design of architecture, due to the limitation of teaching conditions, can never attempt and explore a way of combining teaching and practice teaching. Therefore, the author based on the above reasons and problems, combining with the landscape design teaching reform, to take this opportunity to carry out the competition.

Design Competition Requirements and Forms. The author combined with the real conditions of the design modification area, puts forward the design requirement and content of the competition are as follows:

(a)Fully analyzing the environmental characteristics, the characteristics of the institute of architecture and environment, rational layout.

(b)Should be considered for students to expand exchanges in the use of space, create a different spatial experience and feelings of multivariate space;

(c)Ppay more attention to the combination of the site functionality and esthetics working together,

(d)Pay attention to the field of landscape design and the campus landscape of coordination;

(e)Plant configuration should be suitable to optimal tree, highlight the ecological, green area of not less than $65 \%$ of the area of the design, to build the ornamental plants in teaching field.

And, in the race for sichuan university school of undergraduate and graduate, professional unlimited, can be in the form of a personal or group as the unit, the number of each team should not more than five people.

Design Competition Results. The scope of this landscape design contest received the school, a total of 15 piece contestants are in group, participating students covering architecture, landscape design, urban planning, environmental art and other professional undergraduate and graduate student; And, from the landscape, architecture, city planning and design and other professional professors and teachers involved in the design competition. Competition committee invited A construction union college London landscape city the dean professor Eva Castro became head of the judges, the school, planning and landscape architecture of professors and teachers as members of the jury to be involved in the review. For each piece, judges, teachers gave a detailed review opinions and Suggestions. After review comments and vote, 7 piece, a selected first prize, two second prize, third prize, four other honorable mention and honorable mention four, and sets up incentive measures respectively.

Due to the participation of each student, the student work has the higher quality of the competition. Titled "four dimensional" won the first prize in student work, for example, the design 
fully combined the institute of architecture and environmental design of the building site characteristics, and combined with the college of architecture, buildings and environment which consists of four departments: department of architecture, civil engineering, engineering science and force and the composition of environmental science and engineering. The design based on the characteristics of each system, built the different space in the design field, and is independent and has relationship between space and space. This design not only highlight the school characteristics, carrying the faculty culture, create multiple space, extends the teaching base, and to strengthen the idea of ecological design, has fairly strong operability

Second prize of student work "doug bureau" design innovative and combined with actual situation closely. The design institute of architecture and environment is analyzed the characteristics of various disciplines, namely, architecture, landscape design, urban planning, civil engineering, water supply and drainage engineering, environmental science and environmental engineering, engineering mechanics, based on the characteristics of these disciplines, respectively, set up a communication space, exhibition space, open space, meeting space, etc.; And the adoption of a certain design pattern language will be the space in the design field in accordance with the beautiful setting with functional requirements. Has a strong scientific basis for the design, considering the characteristics of the school building on the function, design also has a strong practical significance.

Second prize student work Archi - land design conception is to extract the root Archi in Architecture, Architecture and Landscape Landscape prefixes in land, merged into the Archi - land as a design conception, expressed the people to the scene and beauty of the earth, pure psychological experience of yearning. The design combined with the characteristics of the institute of architecture and environment, the atrium, roof greening landscape and school peripheral environment be in harmony are an organic whole, its design flow is clear, the design field as a part of students work, study and life; Functional space layout is reasonable, the space is done up handing down, and get the maximum use; Pay attention to the design of key nodes, build the space a lot of fun, carefully designed landscape structure increased the personality characteristics of the space.

The Landscape Design Course Experimental Teaching Base Construction. The introduction of the design competition project for the experimental teaching reform provides a good platform, in order to further develop the landscape design has laid a good groundwork for the construction of experimental teaching. Landscape design experiment teaching base for the construction of the project will adopt green roof design. In the design competition award-winning works, will be as a reference of the green roof design. Green roof is widely recognized by improving city green coverage rate, slow down the urban heat island effect "of one of the most effective way, is also the most cheap way of greening urban areas. It not only can effectively improve the roof glare, beautify the city landscape and ecological functions, for the user's physical and mental health also play a positive role, is indispensable in the design of the green building a technology. Project personnel will be successful in the colleges and universities at present, roof greening design case of on-the-spot investigation and research, such as Taiwan university, Taiwan university, makes the school of architecture and environment building the green roof. This not only provides an opportunity for the students to participate in the practice, but also provides a learning for the students for the future of green base.

This article introduces three competition scheme is the author from the award-winning scheme selected reasonable and operable. First prize plan "four dimensional" atrium design and roof design coordination, fully combines the school of architecture and environment building use function, and the characteristics of the subject distribution, but plants the appropriate experimental base for the demand of the practice teaching shard to deepen and refine the atrium can add variety to increase the space to surround close and change; Second prize plan "doug bureau" practical, functional, but the design of the slide is not reality, and too much hard landscape, in the ecosystem of the design and agreeableness can strengthen; Second prize solution Archi-land design conception and the overall visual effect is good, but its design consideration is not comprehensive, and lack of detail design. The author will eventually be selected from the above design a strongest operability, and landscape professional two main courses, or combining landscape garden plants and landscape 
engineering technology courses. Environment of atrium and roof greening from plan design to the implementation of specific work, will be completed by the professional teacher guide students. The benefits of this approach is as follows: (1)through the old design, lets the student in the curriculum design more creative and practical; (2)it is through this process, let students more actively deepening design; Three can make teaching research have new breakthrough, through and landscape garden plants and landscape engineering technology is the combination of the two main courses, experiment teaching methods, explore the new landscape promote mutual connections between the course, and help the construction of experimental teaching base, it works. At present due to funding, the second phase of the teaching reform is being planned.

\section{Conclusion}

This article from the current domestic exploration on the general situation of the teaching mode, the landscape design course, from the current domestic landscape design problems existing in the teaching of specific analysis, from establishing the diversified teaching pattern of the landscape design of a new intensive research, aims to explore a more suitable for social development needs, is more advantageous to develop students for landscape design of the innovative teaching mode of thinking, cultivating high comprehensive quality, strong practical ability of landscape design class talented person, and thus promote the landscape design industry in our country and the development of landscape architecture education. After thinking of the teaching reform, the author put them into teaching practice and practice inspection of these ideas is effective, improve the students' professional skills. The present status of the landscape design of environmental art specialty course teaching has certain problem, we through the teaching method, curriculum setting, teaching reform, teachers to cultivate solid basic theory, design ability, strong innovation consciousness of professional talents, to improve the teaching quality, build a sound teaching system. Due to the closer to the actual course content more concise, method of teaching students more easy to accept; Practice project combined with the multimedia teaching, and the case analysis, targeted follow the market development, cooperate with landscape practice, improved the students' learning enthusiasm, also added a employment channels. Of course, these measures still need to improve, the exploration of teaching reform will continue, at the same time, also make the cultivation of the students in a diverse landscape design course teaching pattern, landscape and landscape aesthetic appreciation ability to improve, eyes open, eventually create a good landscape design works with a strong taste of new era.

\section{References}

[1] Ma Jian-mei. Environmental art course teaching mode reform of professional landscape design [J]. Anhui Agricultural Science. 2011 (31)

[2] Tang Jun. The development of modern landscape design present situation and trend analysis [J]. Chinese Gardening Abstract. 2012 (9) : 97-2012.

[3] Zhang Wei-wei. Display is analysed the meaning of art in the indoor environment [J]. New Finance and Economics (theory), 2010 (6)

[4] Cheng Kun. Environmental art design professional practicality teaching exploration [J]. Information Science and Technology, 2009 (10) : 732

[5] Ma Rui-dong. The scientific environmental art teaching in colleges and universities study [J]. Philosophy and the Humanities, 2009 (8) 